\title{
Front Matter: Volume 9100
}

, "Front Matter: Volume 9100," Proc. SPIE 9100, Image Sensing Technologies: Materials, Devices, Systems, and Applications, 910001 (16 June 2014); doi: 10.1117/12.2069550

SPIE Event: SPIE Sensing Technology + Applications, 2014, Baltimore, MD, United SPIE. States 


\section{PROCEEDINGS OF SPIE}

\section{Image Sensing Technologies: Materials, Devices, Systems, and Applications}

Nibir K. Dhar

Achyut K. Dutta

Editors

7-8 May 2014

Baltimore, Maryland, United States

Sponsored and Published by

SPIE 
The papers included in this volume were part of the technical conference cited on the cover and title page. Papers were selected and subject to review by the editors and conference program committee. Some conference presentations may not be available for publication. The papers published in these proceedings reflect the work and thoughts of the authors and are published herein as submitted. The publisher is not responsible for the validity of the information or for any outcomes resulting from reliance thereon.

Please use the following format to cite material from this book:

Author(s), "Title of Paper," in Image Sensing Technologies: Materials, Devices, Systems, and Applications, edited by Nibir K. Dhar, Achyut K. Dutta, Proceedings of SPIE Vol. 9100 (SPIE, Bellingham, WA, 2014) Article CID Number.

ISSN: 0277-786X

ISBN: 9781628410372

Published by

SPIE

P.O. Box 10, Bellingham, Washington 98227-0010 USA

Telephone +1 3606763290 (Pacific Time) · Fax +1 3606471445

SPIE.org

Copyright (@ 2014, Society of Photo-Optical Instrumentation Engineers.

Copying of material in this book for internal or personal use, or for the internal or personal use of specific clients, beyond the fair use provisions granted by the U.S. Copyright Law is authorized by SPIE subject to payment of copying fees. The Transactional Reporting Service base fee for this volume is $\$ 18.00$ per article (or portion thereof), which should be paid directly to the Copyright Clearance Center (CCC), 222 Rosewood Drive, Danvers, MA 01923. Payment may also be made electronically through CCC Online at copyright.com. Other copying for republication, resale, advertising or promotion, or any form of systematic or multiple reproduction of any material in this book is prohibited except with permission in writing from the publisher. The CCC fee code is 0277-786X/14/\$18.00.

Printed in the United States of America.

Publication of record for individual papers is online in the SPIE Digital Library.

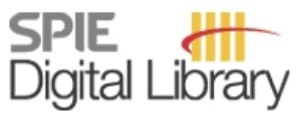

SPIEDigitalLibrary.org

Paper Numbering: Proceedings of SPIE follow an e-First publication model, with papers published first online and then in print and on CD-ROM. Papers are published as they are submitted and meet publication criteria. A unique, consistent, permanent citation identifier (CID) number is assigned to each article at the time of the first publication. Utilization of CIDs allows articles to be fully citable as soon as they are published online, and connects the same identifier to all online, print, and electronic versions of the publication. SPIE uses a six-digit CID article numbering system in which:

- The first four digits correspond to the SPIE volume number.

- The last two digits indicate publication order within the volume using a Base 36 numbering

system employing both numerals and letters. These two-number sets start with 00, 01, 02, 03, 04, 05, 06, 07, 08, 09, 0A, 0B ... 0Z, followed by 10-1Z, 20-2Z, etc.

The CID Number appears on each page of the manuscript. The complete citation is used on the first page, and an abbreviated version on subsequent pages. Numbers in the index correspond to the last two digits of the six-digit CID Number. 


\section{Contents}

vii Conference Committee

\section{SESSION 1 ADVANCED FOCAL PLANE ARRAY TECHNOLOGIES I}

910003 Uncooled microbolometers at DRS and elsewhere through 2013 (Invited Paper) [9100-2]

G. D. Skidmore, C. J. Han, C. Li, DRS Technologies, Inc. (United States)

910004 Performance of PHOTONIS' low light level CMOS imaging sensor for long range observation [9100-3]

L. E. Bourree, PHOTONIS Digital Imaging LLC (United States)

910005 A 33-mpixel 120-fps CMOS image sensor using 0.11- $\mu \mathrm{m}$ CIS process (Invited Paper) [9100-4]

T. Yasue, T. Hayashida, J. Yonai, NHK Japan Broadcasting Corp. (Japan); K. Kitamura, NHK Japan Broadcasting Corp. (Japan) and Shizuoka Univ. (Japan); T. Watabe, NHK Engineering System, Inc. (Japan) and Shizuoka Univ. (Japan); H. Shimamoto, H. Ootake, NHK Japan Broadcasting Corp. (Japan); T. Kosugi, T. Watanabe, S. Aoyama, Brookman Technology, Inc. (Japan); S. Kawahito, Shizuoka Univ. (Japan) and Brookman Technology, Inc. (Japan)

\section{SESSION 2 ADVANCED FOCAL PLANE ARRAY TECHNOLOGIES II}

910006 Development of low-cost high-performance multispectral camera system at Banpil (Invited Paper) [9100-5]

P. Oduor, G. Mizuno, R. Olah, A. K. Dutta, Banpil Photonics, Inc. (United States)

910009 Wafer-level 3D integration with 5 micron interconnect pitch for infrared imaging applications [9100-8]

M. Lueck, J. Lannon Jr., C. Gregory, D. Malta, A. Huffman, D. S. Temple, RTI International (United States)

9100 OB InAsSb detector and FPA data and analysis (Invited Paper) [9100-10]

A. I. D'Souza, E. Robinson, A. C. Ionescu, D. Okerlund, DRS Sensors \& Targeting Systems, Inc. (United States); T. J. De Lyon, R. D. Rajavel, H. Sharifi, HRL Labs., LLC (United States);

N. K. Dhar, Defense Advanced Research Projects Agency (United States);

P. S. Wijewarnasuriya, U.S. Army Research Lab. (United States); C. Grein, Univ. of Illinois at Chicago (United States)

\section{SESSION $3 \quad$ NOVEL TECHNOLOGIES FOR IMAGING}

9100 OC Materials for imaging acousto-optic tunable filters (Invited Paper) [9100-11]

N. Gupta, U.S. Army Research Lab. (United States) 
9100 OF Miniaturized imaging spectrometer based on Fabry-Perot MOEMS filters and HgCdTe infrared focal plane arrays (Invited Paper) [9100-14]

S. Velicu, C. Buurma, J. D. Bergeson, EPIR Technologies, Inc. (United States); T. S. Kim, EPIR Technologies, Inc. (United States) and Univ. of California, Santa Cruz (United States); J. Kubby, Univ. of California, Santa Cruz (United States); N. Gupta, U.S. Army Research Lab. (United States)

$9100 \mathrm{OH} \quad$ Recent progress of room temperature $\mathrm{THz}$ sources based on nonlinear frequency mixing in quantum cascade lasers (Keynote Paper) [9100-16]

M. Razeghi, Q. Y. Lu, N. Bandyopadhyay, S. Slivken, Y. Bai, Northwestern Univ. (United States)

91000 Ol Case for small pixels: system perspective and FPA challenge (Invited Paper) [9100-17] J. Robinson, M. Kinch, M. Marquis, D. Littlejohn, K. Jeppson, DRS RSTA, Inc. (United States)

9100 0J Performance benefits of sub-diffraction sized pixels in imaging sensors (Invited Paper) [9100-18]

J. T. Caulfield, J. A. Wilson, Cyan Systems (United States); N. K. Dhar, Defense Advanced Research Projects Agency (United States)

9100 OK Effect of dense planer focal plane array on device performances [9100-19] T. Lin, R. Olah, A. K. Dutta, Banpil Photonics, Inc. (United States)

$9100 \mathrm{OL} \quad$ Enabling more capability within smaller pixels: advanced wafer-level process technologies for integration of focal plane arrays with readout electronics (Invited Paper) [9100-20]

D. S. Temple, E. P. Vick, M. R. Lueck, D. Malta, RTI International (United States); M. R. Skokan, C. M. Masterjohn, M. S. Muzilla, DRS Technologies, Inc. (United States)

9100 OM Direct optimization of LWIR systems for maximized detection range and minimized size and weight (Invited Paper) [9100-21]

R. Bates, K. Kubala, FiveFocal LLC (United States)

9100 0N Nanostructured detector technologies for optical sensing applications (Invited Paper) [9100-22]

A. K. Sood, R. E. Welser, Y. R. Puri, Magnolia Optical Technologies, Inc. (United States); N. K. Dhar, Defense Advanced Research Projects Agency (United States); D. L. Polla, Univ. of Minnesota (United States); P. Wijewarnasuriya, M. Dubey, U.S. Army Research Lab. (United States)

\section{POSTER SESSION}

910000 Applications of the Lambert W function to analyze digital camera sensors [9100-23] D. Villegas, Univ. EAFIT (Colombia) 
9100 OP Application of the Ornstein-Uhlenbeck equations for biomedical image processing [9100-24]

J. P. Mesa López, Univ. EAFIT (Colombia)

$91000 Q \quad$ Improvements to crystal quality of sapphire grown by the Kyropoulos method [9100-25] J. P. Ciraldo, J. Levine, H. Ganegoda, Rubicon Technology Inc. (United States)

9100 OR Design of HgCdTe heterojunction photodiodes on Si substrate [9100-27]

P. Zhang, Shanghai Institute of Technical Physics (China) and Univ. of Chinese Academy of Sciences (China); Z. H. Ye, Shanghai Institute of Technical Physics (China); Y. Y. Chen, Shanghai Institute of Technical Physics (China) and Univ. of Chinese Academy of Sciences (China); C. Lin, X. N. Hu, R. J. Ding, L. He, Shanghai Institute of Technical Physics (China)

9100 OS New approach for underwater imaging and processing [9100-28]

Y. Wen, W. Tian, B. Zheng, G. Zhou, H. Dong, Q. Wu, Qingdao Academy for OptoElectronics Engineering (China)

9100 OT Analysis and simulation of a new kind of noise at the input stage of infrared focal plane array [9100-29]

Z. Huang, Y. Chen, S. Huang, J. Fang, Shanghai Institute of Technical Physics (China)

9100 OU Responsivity performance of extended wavelength InGaAs shortwave infrared detector arrays [9100-30]

T. Li, S. Deng, X. Li, X. Shao, H. Tang, H. Gong, Shanghai Institute of Technical Physics (China)

9100 0W Image quality assessment of 2-chip color camera in comparison with 1-chip color and 3-chip color cameras in various lighting conditions: initial results [9100-32]

S. Adham Khiabani, Y. Zhang, F. Fathollahi, Univ. of New Brunswick (Canada)

$91000 \mathrm{X}$ Influence of image compression on the quality of UNB pan-sharpened imagery: a case study with security video image frames [9100-33]

S. Adham Khiabani, Y. Zhang, F. Fathollahi, Univ. of New Brunswick (Canada)

9100 OY Support for both touch sensing and fingerprint scan with in-cell capacitive LCD [9100-34] P. Koundinya, X. Zhao, T. Feng, W. Shi, Univ. of Houston (United States)

910010 Performance of near-infrared InGaAs focal plane array with different series resistances to p-InP layer [9100-36]

X. Shao, X. Li, T. Li, Z. Huang, Y. Chen, H. Tang, H. Gong, Shanghai Institute of Technical Physics (China)

910011 Wide dynamic range and high-sensitivity CMOS active pixel sensor using output voltage feedback structure [9100-57]

S.-H. Jo, M. Bae, B.-S. Choi, J. Kim, J.-K. Shin, Kyungpook National Univ. (Korea, Republic of)

Author Index 
Proc. of SPIE Vol. $9100910001-6$

Downloaded From: https://www.spiedigitallibrary.org/conference-proceedings-of-spie on 26 Apr 2023 Terms of Use: https://www.spiedigitallibrary.org/terms-of-use 


\section{Conference Committee}

Symposium Chair

David A. Whelan, Boeing Defense, Space, and Security (United States)

Symposium Co-chair

Wolfgang Schade, Technische Universität Clausthal (Germany) and

Fraunhofer Heinrich-Hertz-Institut (Germany)

Conference Chairs

Nibir K. Dhar, Defense Advanced Research Projects Agency (United States)

Achyut K. Dutta, Banpil Photonics, Inc. (United States)

Conference Program Committee

Homayoon Ansari, Jet Propulsion Laboratory (United States)

Arvind I. D'Souza, DRS Sensors \& Targeting Systems, Inc.

(United States)

Ravi Dutt, Booz Allen Hamilton Inc. (United States)

Michael D. Gerhold, U.S. Army Research Office (United States)

John E. Hubbs, Ball Aerospace \& Technologies Corporation (United States)

Nobuhiko P. Kobayashi, University of California, Santa Cruz (United States)

Sanjay Krishna, The University of New Mexico (United States)

Robert Olah, Banpil Photonics, Inc. (United States)

Adam Piotrowski, VIGO Systems S.A. (Poland)

Siva Sivananthan, EPIR Technologies, Inc. (United States)

Krishna Swaminathan, Intel Corporation (United States)

Rama Venkatasubramanian, RTI International (United States)

Priyalal S. Wijewarnasuriya, U.S. Army Research Laboratory

(United States)

\section{Session Chairs}

1 Advanced Focal Plane Array Technologies I

Nibir K. Dhar, Defense Advanced Research Projects Agency (United States)

Achyut K. Dutta, Banpil Photonics, Inc. (United States) 
2 Advanced Focal Plane Array Technologies II

Nibir K. Dhar, Defense Advanced Research Projects Agency (United States)

Achyut K. Dutta, Banpil Photonics, Inc. (United States)

3 Novel Technologies for Imaging

Qiaoqiang Gan, University at Buffalo (United States)

Achyut K. Dutta, Banpil Photonics, Inc. (United States)

$4 \quad$ Small Pixels and Related Technologies

Nibir K. Dhar, Defense Advanced Research Projects Agency (United States)

Patrick Oduor, Banpil Photonics, Inc. (United States) 